\title{
Leaching experiments in recent tephra deposits from Talang volcano (West Sumatra), Indonesia
}

\begin{abstract}
Tephra deposits are prone to leaching because of their high contents of easily weatherable primary minerals. Rapid weathering of pristine tephra results in soil solutions becoming saturated with soluble cations such as calcium, magnesium and potassium which are major nutrient elements essential for plant growth. Determining cations and phosphate leached from tephra deposits is important for understanding the geochemical weathering of the volcanic materials. Mt. Talang erupted on April 12, 2005, depositing basalto-andesitic ash over portions of the Solok district in West Sumatra, Indonesia. A leaching study was conducted to examine the chemical fluxes of cations from these tephra deposits in closed-batch reaction vessels. The tephra samples were leached with de-ionized water, organic (citric and oxalic) and inorganic (nitric and sulfuric) acids for 60 days in the laboratory at temperatures of 10 , 27 and $40{ }^{\circ} \mathrm{C}$, respectively. The leachates were collected after $24 \mathrm{~h}$, and after 10, 30, and 60 days. Up to 30 days, leaching of the tephra samples with water decreased leachate $\mathrm{pH}$ from 6.75 to 4.51 . Leachate $\mathrm{pH}$ was also noticed to decrease from 3.85 to $3.11,3.25$ to $2.71,3.20$ to 2.71 and 3.03 to 2.39 due to leaching with citric acid, oxalic acid, nitric acid and sulfuric acid, respectively. After 60 days, leaching with water has decreased the $\mathrm{pH}$ by $0.9-2.9$ units, whereas that with citric and sulfuric acids by $0.06-0.24$ units; however, leaching with oxalic and nitric acids has increased the $\mathrm{pH}$ by $0.16-1.38$ units. The release of cations from the Mt. Talang tephra was in the decreasing order of $\mathrm{Ca}>\mathrm{Mg}>\mathrm{K}>\mathrm{Na}$. The rate of initially dissolved calcium was very high. In contrast, the amount of dissolved $\mathrm{K}$ and $\mathrm{Na}$ were low in the beginning, but increased sharply after 10 days. Over the next 2 months, there was a distinct decrease in the concentration of $\mathrm{Ca}$ and $\mathrm{Mg}$. The amount of $\mathrm{P}$ released by water, citric, nitric, sulfuric and oxalic acid after $24 \mathrm{~h}$ was 237, 349, 681, 964 and $1057 \mathrm{mg}$ of P2O5 $\mathrm{kg}-1$, respectively, at the low temperature of $10{ }^{\circ} \mathrm{C}$ but the values tended to increase with increasing temperature. It was noticed that the amount of dissolved $\mathrm{P}$ decreased exponentially with time of leaching, which was highly correlated when using oxalic and sulfuric acid. At the end of the incubation period, dissolved $\mathrm{P}$ accounted for less than $36 \mathrm{mg}$ of $\mathrm{P} 2 \mathrm{O} 5 \mathrm{~kg}-1$. Higher amounts of total dissolved $\mathrm{P}$ were obtained when using inorganic (sulfuric and nitric) acids compared with those of organic (oxalic and citric) acids.
\end{abstract}

Keyword: Volcanic ash, Tephra, Weathering, Geochemistry, Talang volcano 